\title{
Follicular development, ovulation, fertilization and fetal development in tenrecs (Tenrec ecaudatus)*
}

\author{
M. E. Nicoll and P. A. Racey \\ Department of Zoology, University of Aberdeen, Aberdeen AB9 2TN, U.K.
}

\begin{abstract}
Summary. Reproduction in female tenrecs was studied on Praslin Island ( $4^{\circ} 20^{\prime} \mathrm{S}$, $55^{\circ} 45^{\prime} \mathrm{E}$ ) in the Seychelles from November 1977 to September 1980 . Dissection and histological examination of reproductive tracts revealed that each ovary is encapsulated in a bursa. Polyovular follicles were abundant and contained up to 5 oocytes. The occurrence of more implanted fetuses than corpora lutea (CL) indicated successful polyovuly in $25 \%$ of pregnancies. No antrum was observed during follicular growth at oestrus, and follicles were relatively small at maturation, reaching a maximum diameter of $570 \mu \mathrm{m}$. Ovulation involves a gentle extrusion of the granulosa and ovum into the periovarian space. Spermatozoa were abundant in the female reproductive tract including the periovarian space at oestrus. Spermatozoa penetrated the looselypacked theca of mature follicles and were present in $\mathrm{CL}$, indicating that intrafollicular fertilization may occur. The relatively small $C L$ formed by eversion, reaching a maximum size after implantation. Fusion of up to four CL occurred in the ovaries of $41 \%$ of pregnant females. Polyovulation in the tenrec was confirmed by the occurrence of $10.4 \pm 0.5$ (mean \pm s.e.m.) CL and $9.7 \pm 0.5$ (mean \pm s.e.m.) implantations. Resorption occurred in $74 \%$ of 19 dissectable pregnancies, occurring in both uterine horns in $26 \%$ of pregnancies. Coefficients of variation in weights of fetuses in each litter were $10 \cdot 0-26 \cdot 8 \%$, with the largest value corresponding to $273 \%$ variation in fetus weights. Litter size in the Seychelles tenrecs was smaller than in the same species in Madagascar (17.1 \pm 1.9 implantations) where the tenrec is native.
\end{abstract}

\section{Introduction}

Reproduction within members of the Family Tenrecidae (Insectivora) has been studied in only a few species (for review, see Eisenberg \& Gould, 1970; Harrison \& Weir, 1977; Nicoll, 1982). Like other tenrecs which have been studied, the largest species, Tenrec ecaudatus, breeds during the austral summer wet season in Madagascar, where most species are endemic. After a gestation of about 60 days, birth in the tenrec coincides with the January peak in rainfall and lactation is completed within 28-32 days (Eisenberg \& Gould, 1970). Anoestrus follows and the tenrecs fatten rapidly to enter 6-month seasonal hypothermia (Rand, 1935; Eisenberg \& Gould, 1970).

Histological examination of the reproductive tract in females of two species in the subfamily Tenrecinae, Setifer setosus and Hemicentetes semispinosus, revealed that no antrum is formed during ovarian follicular development and maturation, and that intrafollicular fertilization may occur (Strauss, 1938, 1939). No attempts have since been made to verify these unusual findings in these or other tenrec species. Therefore, it is an aim of the present study to determine whether antrum formation and intrafollicular fertilization occur in the tenrec, $T$. ecaudatus. The present study also describes additional changes in the female's reproductive tract during the breeding cycle. Litter size 
in the tenrec is amongst the largest recorded for mammals: up to 40 unimplanted blastocysts or up to 32 fetuses per female (Bluntschli, 1938) have been observed in Madagascar, and 25-32 young have been seen foraging with an adult female (Kaudern, 1914; Petter \& Petter-Rousseaux, 1963).

This study was carried out in the Seychelles Islands where the tenrec was introduced about 100 years ago (Racey \& Nicoll, 1984). Annual cycles in thermoregulation, activity and reproduction are similar to those of tenrecs in Madagascar, but occur 1 month earlier in the Seychelles (Nicoll, 1985). Breeding in the Seychelles also occurs throughout the year although most births coincide with the wet season peak in food supply (Nicoll, 1985).

\section{Materials and Methods}

This study was carried out on Praslin Island $\left(4^{\circ} 20^{\prime} \mathrm{S}, 55^{\circ} 45^{\prime} \mathrm{E}\right)$ in the Seychelles, and extended from November 1977 to September 1980. A total of 89 females comprising up to 5 adults each month were collected randomly at night in the forest habitats of Praslin Island. Immature females included in the collection were examined in the same way as were adults, but are not used in this study. Tenrecs were killed by ether inhalation or intra-cardiac pentobarbitone sodium. The females' toothwear was scored on a scale of 1-6 corresponding with increasing wear, giving an estimate of age for females which lived for up to 3 years (Nicoll, 1982). Regular inspection of marked free-ranging tenrecs, showed that toothwear categories were 2-3 during the first breeding season, 3 or 4 increasing to 5 during the second breeding season, and 5-6 during the third breeding season. Each female was dissected, and the reproductive organs removed, weighed and stored in Bouin's fluid. A White's torsion balance was used to weigh materials $<5 \mathrm{~g}$, while heavier materials were weighed with Pesola balances. Fixed material was dehydrated, embedded in paraffin wax, serially sectioned at 4-8 $\mu \mathrm{m}$, and stained with Erlich's haematoxylin and eosin. Measurements were made with an eyepiece graticule calibrated to a micrometer slide. Mean diameters of follicles, oocytes and CL were calculated from two right-angled diameters at the widest section. When CL were fused, the largest right-angled diameters of each lobe were used and each lobe was treated separately.

\section{Results}

\section{Ovarian structure}

Each ovary was enclosed within the periovarian sheath (bursa), which opens into the ostium of the oviduct (Pl. 1, Fig. 1). A convoluted surface gave the ovary a large area (Pl. 1, Fig. 1). Primordial oocytes were closely packed in the ovaries of younger mature females (nulliparous with little toothwear) (Pl. 1, Fig. 2), but their numbers appeared reduced in the ovaries of females with advanced toothwear. Mean ( \pm s.e.m.) ovary weights during anoestrus, pre-pregnancy (seasonally active, before mating during August-October), pregnancy and lactation were $21.8 \pm 1.7 \mathrm{mg}(\mathrm{N}=$ $48), 22.8 \pm 2.0 \mathrm{mg}(\mathrm{N}=14), 33.8 \pm 5.9 \mathrm{mg}(\mathrm{N}=62)$, and $15.3 \pm 0.9 \mathrm{mg}(\mathrm{N}=14)$, respectively. In a sample of 79 females, $33 \%$ had cysts containing clear fluid in the bursa, usually at the junction with the oviduct. Dissected cysts weighed up to $345 \mathrm{mg}$; and cysts occurred in pregnant and nonpregnant females. The rete ovarii were also encysted in all parous and some nulliparous females, the cysts being most extensive in individuals with advanced toothwear (Pl. 1, Fig. 1).

\section{Follicular development, ovulation and fertilization}

Criteria for deciding that a female was in oestrus were a combination of numerous developing follicles, spermatozoa abundant in the reproductive tract, and relatively small CL which were not surrounded by the surface epithelium. Females meeting these criteria were collected following 


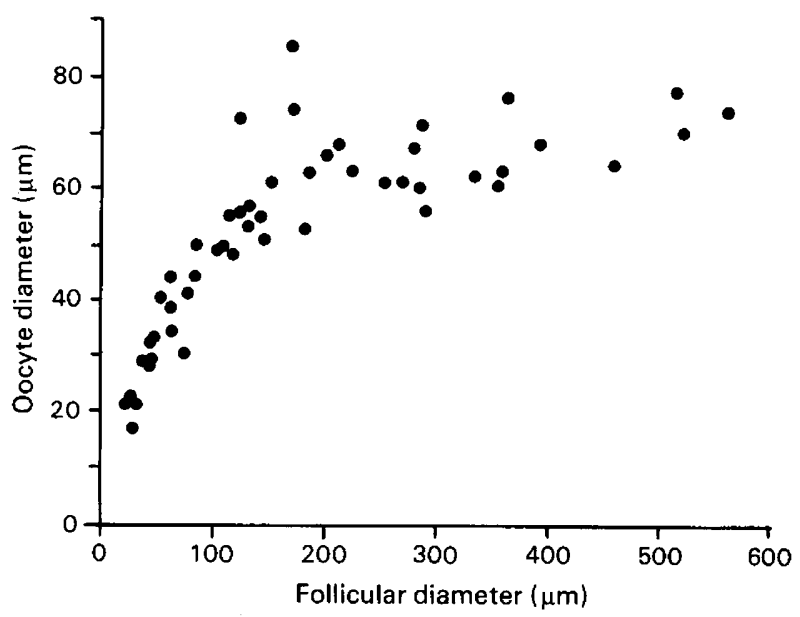

Text-fig. 1. Development of the oocyte and the follicle in the tenrec. For a mammal of the size of the tenrec, the mature follicle is relatively small, presumably because there is no growth associated with antrum formation.

emergence from seasonal torpor, at the beginning of each breeding season. Polyovular primordial follicles were abundant, and many contained up to 5 oocytes, particularly in the ovaries of nulliparous females in which primordial oocytes were closely packed (Pl. 1, Fig. 2). Many primordial follicles developed in the ovaries as oestrus approached, and although a high proportion became atretic, a large number matured to ovulation. Atretic follicles were abundant in the ovaries of all adult females. Initial follicular development involved enlargement of the oocyte from a minimum of $17 \mu \mathrm{m}$ to $50 \mu \mathrm{m}$ while the follicle enlarged to $100 \mu \mathrm{m}$ (Text-fig. 1). Maximum oocyte diameter was $85 \mu \mathrm{m}$. Theca cells were first seen surrounding follicles with a diameter of $60-75 \mu \mathrm{m}$, and when oocyte diameter was $30-45 \mu \mathrm{m}$. The diameter of mature oocytes was $65-85 \mu \mathrm{m}$. As the follicle expanded from $100 \mu \mathrm{m}$ to a maximum recorded diameter of $570 \mu \mathrm{m}$, thecal cells differentiated into externa and interna layers. The granulosa became spongy in appearance, while those cells closest to the zona pellucida became columnar with their long axes forming a radius to the zona pellucida (P1. 1, Fig. 3). Polyovular primary and secondary follicles containing up to 4 oocytes were found within the ovaries of 4 oestrous females. In some follicles, the zona pellucida provided the only separation between oocytes (P1. 1, Fig. 4), but in others oocytes were also separated by granulosa cells (PI. 1, Fig. 5), particularly in larger follicles in which granulosa cells were more abundant. No antrum was observed at any stage of follicular growth.

Vascularization of the theca became evident as the follicle approached maximum diameter ( $\mathrm{Pl}$. 2, Fig. 6). As this occurred, thecal cells took on a loosely-packed appearance, while the oocyte migrated to lie close to the basement membrane (Pl. 2, Fig. 6). Mature follicles frequently contained 2 oocytes (PI. 2, Figs $7 \& 8$ ) which are likely to be two daughter cells of a divided oocyte. The next observed phase of the ovulatory sequence was a ruptured follicle which had shed the oocyte (Pl. 2, Fig. 9). It appears that the theca becomes progressively perfused by blood, the cells are loosened, and the basement membrane gives way to allow the granulosa to extrude into the periovarian space, carrying the oocyte.

Spermatozoa were abundant in the vagina, uterine horns, oviducts and the periovarian space when developing ovarian follicles were abundant and relatively small $\mathrm{CL}$ which were not covered by an epithelial membrane were present. The greatest accumulation of spermatozoa occurred where they clustered within folds of the oviduct wall, with their heads against or in contact with the wall, and the tails extending into the lumen of the oviduct (Pl. 2, Fig. 10). Within the periovarian space, spermatozoa were most abundant in small pockets formed by the convolutions of the ovary 


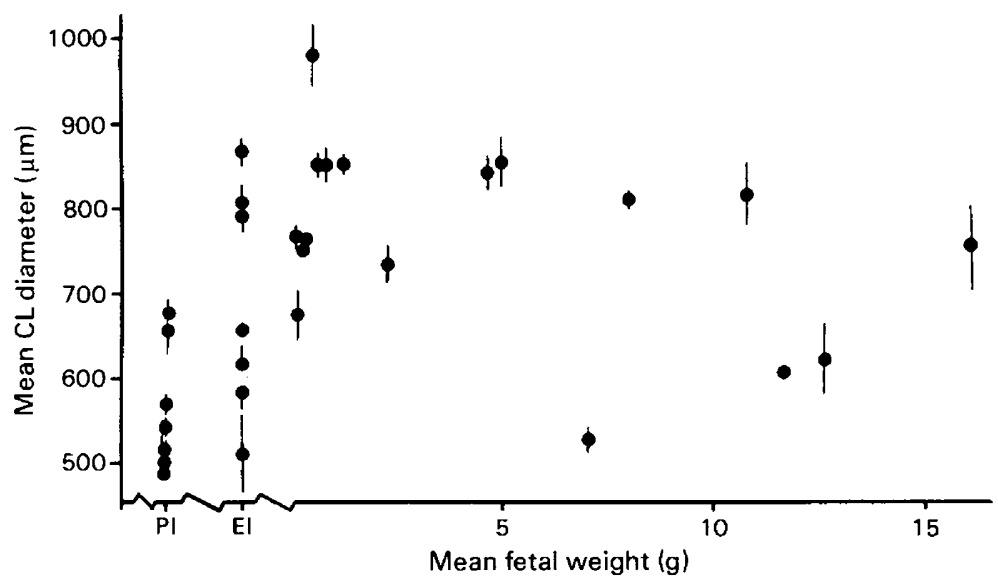

Text-fig. 2. Changes in the size of the corpus luteum (mean \pm s.e.m. CL diameter in the paired ovaries) during pregnancy. Diameters of corpora lutea were variable but tended to be largest when fetuses weighed $100-500 \mathrm{mg}$. PI $=$ preimplantation, $\mathrm{EI}=$ early, undissectable conceptuses.

surface (Pl. 3, Fig. 11) or between closely packed mature follicles. In addition, spermatozoa penetrated into the loosely-packed theca of mature follicles, to a depth of several cells (Pl. 3, Fig. 12). They were also frequently embedded within CL, but whether they were present among the granulosa cells before luteinization was not established.

Morulae were the first observed post-ovulatory stages in this study and they included what were likely to be twin morulae (Pl. 3, Fig. 13).

\section{The corpus luteum}

Each CL formed by eversion of the luteinized granulosa, and was fungiform (P1. 3, Fig. 14). Luteinization began after ovulation (compare P1. 2, Fig. 9 and Pl. 3, Fig. 14). Luteal cells in newlyformed CL were closely packed but well supplied by capillary blood vessels. The surface epithelium covered the CL before implantation (Pl. 3, Fig. 14). Mean diameter of the ovoid CL expanded from a range of $480-680 \mu \mathrm{m}$ before implantation to a maximum of $680-980 \mu \mathrm{m}$ when the fetuses weighed approximately $200 \mathrm{mg}$ (Text-fig. 2). Thereafter, mean CL diameter decreased before parturition. The CL became markedly vacuolated in late pregnancy (Pl. 3, Fig. 15).

\section{PLATE 1}

Fig. 1. Transverse section of the tenrec ovary. The ovary lies completely encapsulated in the bursa and has a large surface area owing to deep invaginations. This ovary has two cysts (c) within the bursa. Such cysts, together with cysts of the rete ovarii, were common. $\times 9$.

Fig. 2. Closely packed and polyovular primordial follicles. Primordial oocytes may be contiguous with several enclosed within a single basement membrane and layer of epithelial cells to form a polyovular follicle (arrow). Polyovular primordial follicles were particularly abundant in the tenrec's first breeding season. $\times 200$.

Fig. 3. A developing follicle. A distinct corona radiata is evident around the zona pellucida. Eosinophilic granules are present in the oocyte. This is probably yolk material. $\times 160$.

Fig. 4. A polyovular secondary follicle. The 3 oocytes are separated by the zona pellucida. $\times 320$.

Fig. 5. A polyovular secondary follicle. The 3 oocytes are separated by the granulosa. $\times 160$. 
PLATE 1

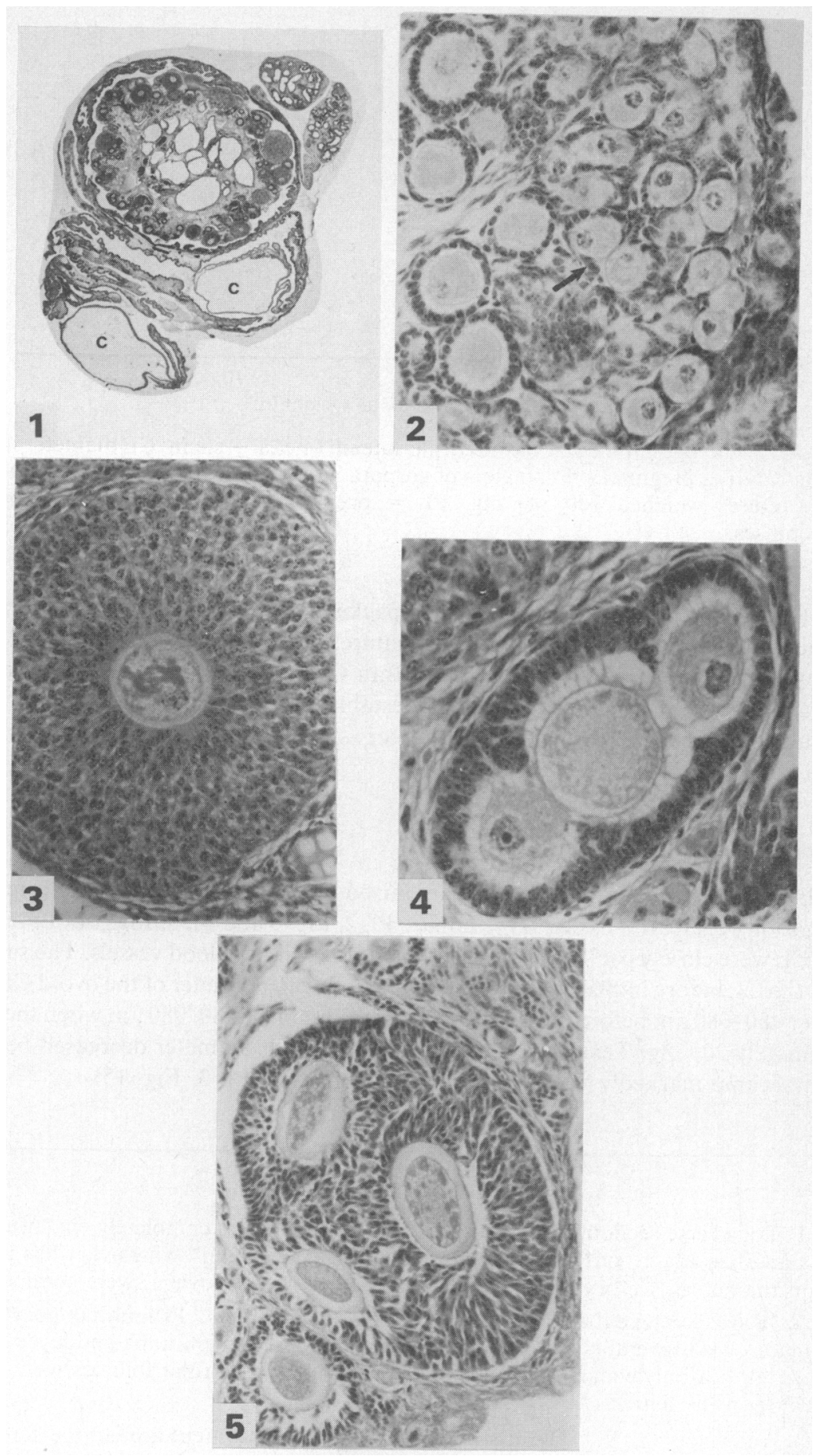

(Facing p. 50) 

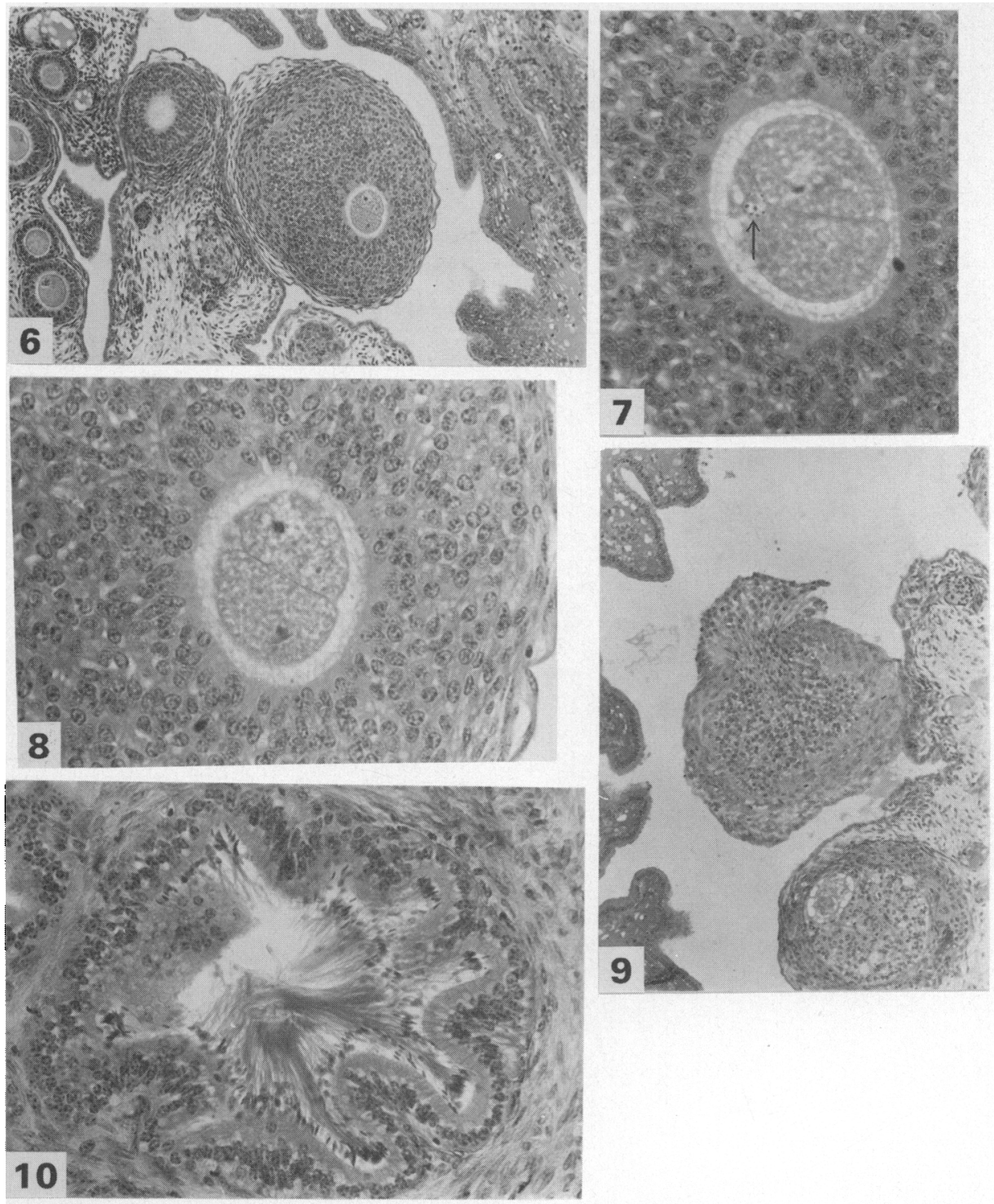

Fig. 6. A mature follicle approaching ovulation. The theca interna becomes loosely-packed and is permeated by blood corpuscles before ovulation. At the same time, the oocyte (which has divided into two daughter cells in this follicle) migrates towards the basement membrane. The large surface area of the ovary is also well illustrated. $\times 80$.

Fig. 7. Division of an oocyte in a mature follicle. Even cleavage of the oocyte regularly occurred within a mature follicle. The two daughter oocytes (also shown in Fig. 8) are accompanied by what appears to be a polar body (arrow). Division of a single oocyte to produce two healthy daughter cells may give rise to twins after fertilization. $\times 320$.

Fig. 8. Division of an oocyte in a mature follicle. The nuclei of two daughter cells from a divided oocyte (shown in Fig. 7). × 320 .

Fig. 9. A recently ovulated follicle. The theca forms an open cup from which the granulosa extrudes into the periovarian space. $\times 80$.

Fig. 10. Spermatozoa in the oviduct of an oestrous female. $\times 320$. 


\section{PLATE 3}

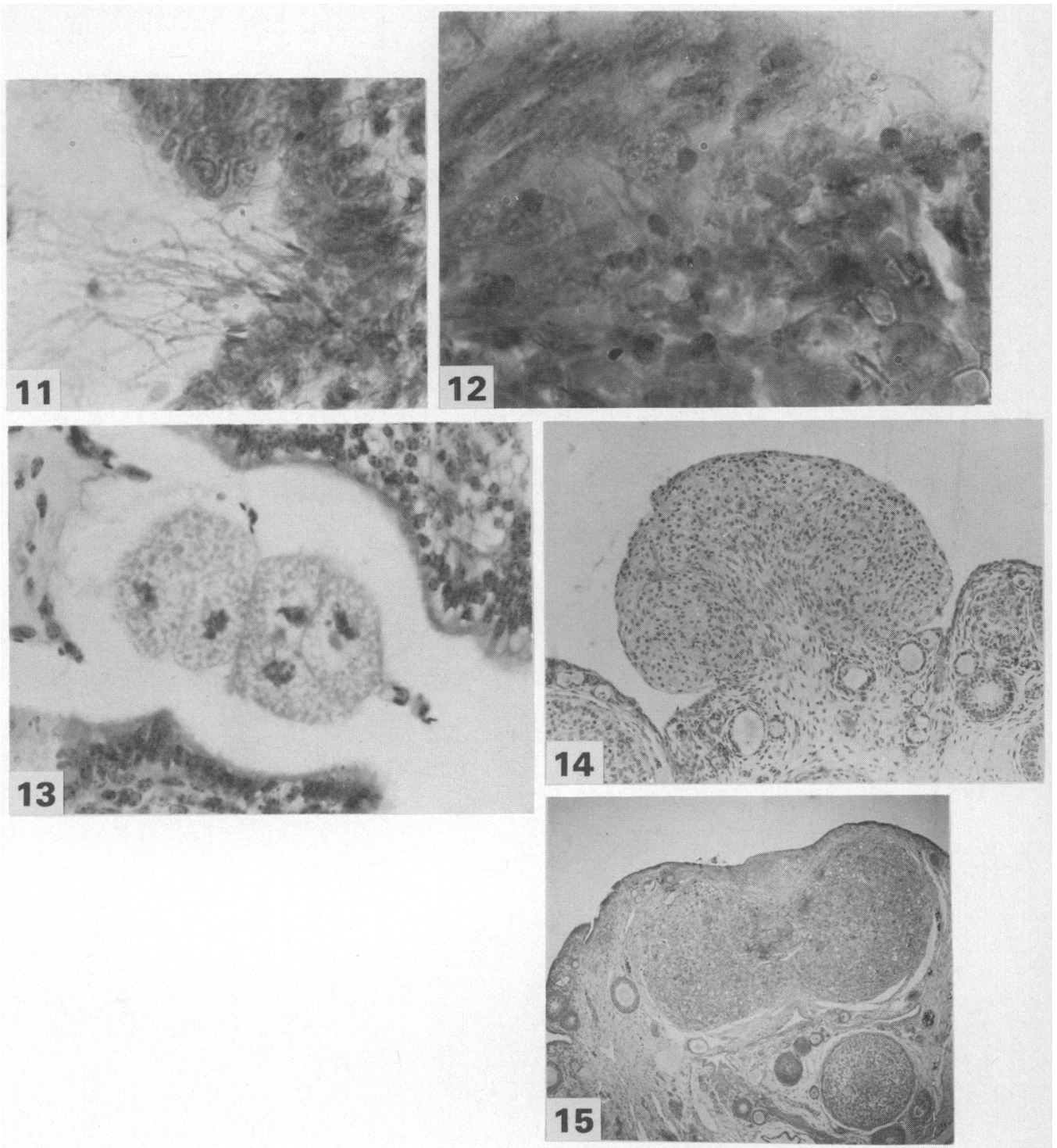

Fig. 11. Spermatozoa in a pocket of the ovary surface. $\times 640$, oil immersion.

Fig. 12. Spermatozoa within the theca of a mature follicle. The theca cells are permeated by blood corpuscles. Several spermatozoa are present. $\times 800$, oil immersion.

Fig. 13. Twin morulae in the oviduct of an oestrous female. The zona pellucida surrounding these morulae has been dissolved in fixative, but these morulae are probably twins. $\times 320$.

Fig. 14. A corpus luteum before encapsulation by the surface epithelium. $\times 80$.

Fig. 15. Fused corpora lutea during late pregnancy. Both CL are vacuolated. $\times 80$. 
The mean ( \pm s.e.m.) number of $C L$ in 34 pregnant females was $10.4 \pm 0.5$ (range 3-18). Fusion of $\mathrm{CL}$ occurred in $41 \%$ of these females. Out of $354 \mathrm{CL}, 87 \%$ were separate and single, $10 \%$ fused into pairs (Pl. 3, Fig. 15), and groups of 3 and 4 fused CL occurred twice and once, respectively. Fused CL occurred at all stages of pregnancy, with the earliest evident in the ovaries of oestrous females, in which follicles were maturing to ovulation.

Corpora lutea atretica coincided with relatively small numbers of $\mathrm{CL}$, and occurred only in ovaries of females showing advanced toothwear.

\section{Fetal development}

The mean \pm s.e.m. number of detectable implantations per pregnancy was $9 \cdot 7 \pm 0.5(n=30)$, and was not significantly different from the mean number of $C L(t=0.91$, d.f. $=63)$. However, the frequency of preimplantation losses was obscured because more implanted fetuses than CL were observed in $6(25 \%)$ out of 24 pregnancies, probably as a result of polyovulation. Mean \pm s.e.m. numbers of $C L$ and fetuses within pregnancies showing polyovulation were $11.0 \pm 0.4$ and $12 \cdot 3 \pm$ $0 \cdot 4$, respectively. Fetuses outnumbered CL by one in all but one of these pregnancies, in which the number of fetuses exceeded CL by three. The incidence of polyovulation was likely to have been higher because its contribution to litter size was masked by high preimplantation losses, with $63 \%$ of pregnant females $(N=24)$ showing fewer implantations than CL.

Blastocysts implanted anywhere in the uterine lumen, on the antimesometrial and mesometrial sides. Fetal spacing was regular when the uterine horn contained 4 or more fetuses, but irregular in 3 out of 17 uterine horns containing 2-3 fetuses. Disparity between the number of implantation sites and $\mathrm{CL}$ in ipsilateral horns indicates that blastocysts may implant in the uterine horn opposite the ovary of origin, but this was complicated by the occurrence of polyovulation and differential embryo survival. If such transmigration occurred, it did not result in equal numbers of implantations in each horn.

Coefficients of variation of fetus weight for 17 litters comprising 3 or more fetuses averaged $14.3 \%$ and ranged from 10.0 to $26.8 \%$. The largest value corresponded to $273 \%$ variation in fetus weights. Coefficients of variation did not correlate with mean fetus weight of the litter $(r=0 \cdot 138$,

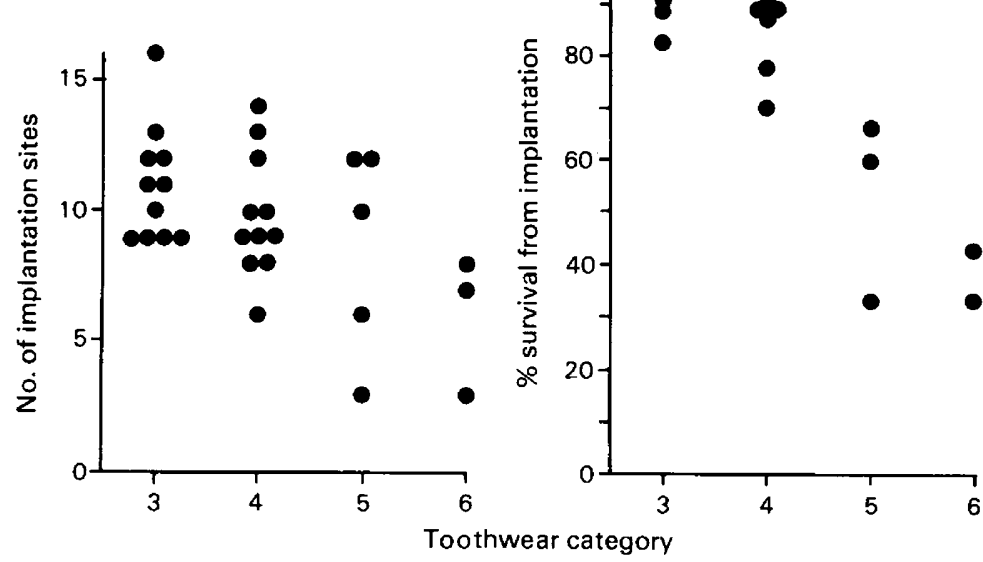

Text-fig. 3. The number of implantations and percentage survival of implapted embryos in relation to maternal toothwear (a measure of maternal age, see text). Number of in santifitions, Spearman's rank correlation coefficient, $r_{\mathrm{s}}=0.432, \mathrm{t}=5.34, P<0.001$. 
d.f. $=15)$ or fetus number $(r=0 \cdot 316$, d.f. $=15)$, nor was there any clear pattern in the distribution within the uterus of relatively small or relatively large fetuses.

Of the 19 dissectable pregnancies, $74 \%$ (14) had one or more resorbed fetuses. Resorption occurred in one horn only in $47 \%$ (9) of pregnancies, and in both uterine horns in $26 \%$ (5). Resorption occurred anywhere along the length of a horn and within individual horns containing $1-8$ conceptuses (the minimum and maximum number of implantations, respectively).

\section{Implantation and conceptus survival in relation to maternal age}

Toothwear was used as the index of maternal age. The number of detectable implantations declined with increasing toothwear (Spearman's rank correlation coefficient, $r_{\mathrm{s}}=-\mathbf{0 . 4 3 2 , \mathrm { t } =}$ 5.34, $P<0.001$ ) (Text-fig. 3). Percentage survival of the implanted embryos at the time of dissection also declined with toothwear (Text-fig. 3), although some females with advanced toothwear were clearly capable of maintaining all implanted fetuses up to the time of dissection.

\section{Discussion}

Extensive ramification of rete ovarii in the tenrec is similar to that in a related species, $H$. semispinosus (Landau, 1938). Cysts in these structures do not appear to obstruct reproduction in the tenrec studied here. Byskov (1974) proposed that the rete ovarii are necessary for follicular formation in mice, and similar extensive rete ovarii may be associated with the abundance of primordial follicles in tenrecs ( $T$. ecaudatus). Further facilitation of ovulation of large numbers of oocytes may result from the deep invaginations in the ovary surface. Similar ovarian architecture in the plains viscacha, Lagostomus maximus, probably facilitates polyovulation (Weir, 19.71a).

The relatively small size of the mature follicle in the tenrec (see comparative data in Brambell, 1956) may also be associated with polyovulation, but is clearly related to the absence of an antrum, a feature which characterizes at least two other tenrecs, $S$. setosus and $H$. semispinosus (Strauss, 1938, 1939). As increase in size of the follicle to its maximum occurs as a result of antrum formation in typical mammals (Harrison \& Weir, 1977), these tenrecs do not conform to the general correlation between maximum follicle size and body mass (Parkes, 1931; Harrison, 1962). Other exceptions include the plains viscacha, and elephant shrews (Macroscelididae, Elephantulus). Small follicles with small antra in the plains viscacha are probably adaptations to ovulating 200-800 ova at each oestrus (Weir, 1971a). Similarly, mature follicles and antra in species of elephant shrews with high ovulation rates are smaller than those in other macroscelidids which have lower ovulation rates (Tripp, 1971). It would be of great interest in this context to examine ovaries of some oryzorictine and potamogaline tenrecs which bear small litters.

Cohen (1969) proposed that polyovulation occurs so that selection of the most viable embryos can take place, but if this is true, it is surprising that it has arisen in so few mammals (Weir, 1971a). Cohen's (1969) proposal is less applicable to the tenrec than to other polyovulators (Tripp, 1971; Weir, 1971a, b) because losses between ovulation and implantation are relatively small compared to those in elephant shrews and the plains viscacha. Similarly, the restrictions in implantation sites together with regular fetal loss in elephant shrews and the plains viscacha (Tripp, 1971; Weir, $1971 \mathrm{a}, \mathrm{b}$ ), and similar post-natal wastage imposed by the number of nipples in polyovulating marsupials (Hill, 1910; Hartman, 1929) contrast with apparent lack of space restrictions and regular fetal loss in the tenrec.

In the tenrec, litter size is related to the number of oocytes which are shed, and polyovulation therefore may increase the number of conceptuses. Polyovular follicles in other species are usually observed in immature individuals (Hartman, 1926; Kent, 1959, 1960, 1962; Bodemer \& Warnick, 1961a, b; Leach \& Conaway, 1963; Collins \& Kent, 1964; Shehata, 1974). Kent \& Mandel (1968) suggest that polyovular follicles and polynuclear oocytes are abundant immediately following the 
period when circulating oestrogens are at their lowest level. Oocytes probably fail to be separated by epithelial cells and a basement membrane during formation of primordial follicles, because they are closely-packed (Harrison \& Weir, 1977). Few data exist to suggest that polyovular follicles can develop to maturity and shed viable oocytes. For example, polyovulation was recorded in $0.83 \%$ of rabbit pregnancies $(\mathrm{N}=2179)$ (Allen, Brambell \& Mills, 1947), and in only 3 of several hundred white-tailed deer pregnancies (Hesselton, Tanck \& Rice, 1964; Hesselton, 1967). Whether the frequency of polyovulation in tenrecs ( $T$. ecaudatus) compared to other species reflects a mechanism for increasing litter size is unclear, but polyovulation in this species is an important contribution to litter size.

Intrafollicular fertilization is clearly possible in the tenrec. The ovaries are completely enclosed by the bursa preventing loss of spermatozoa into the peritoneal cavity, and spermatozoa are present in the periovarian space, within the thecae and within CL. In addition, the absence of an antrum suggests that ovulation is a gentle process. Similar absence of an antrum is associated with intrafollicular fertilization in other tenrecs (Strauss, 1938, 1939) and the short-tailed shrew, Blarina brevicauda (Pearson, 1944). As spermatozoa are capable of penetrating the loosening theca of mature follicles, they may also continue penetration through the weakening basement membrane to the granulosa, and eventually reach the oocyte. Alternatively, spermatozoa may achieve access to the preovulatory oocyte by penetrating through the granulosa directly if the granulosa gradually exudes through a rupture in the basement membrane.

Extrusion of the granulosa is a precursor to the formation of everted CL, which occurs in all tenrecs so far examined (Strauss, 1938, 1939). While eversion occurs in a number of other insectivores (Dryden, 1969; Tripp, 1971), it is uncommon in other orders. The CL is double the size of the mature follicle in the tenrec, but is relatively small compared to those of other mammals of similar size (see Brambell, 1956). The small size of CL may be related to polyovulation, as Tripp (1971) observed an inverse relationship between CL size and their mean abundance in the ovaries of several species of elephant shrews. In addition, intraovarian fusion of CL may be a result in part of their close proximity. It is of interest that fusion of $\mathrm{CL}$ is also common in certain soricids in which these structures have everted (e.g. Price, 1953; Dryden, 1969; Dryden \& Pucek, 1976).

Spatial variation in both resorption sites and the occurrence of fetal runts in the tenrec contrasts with the distribution of resorption sites (Tripp, 1971; Weir, 1971b) or fetuses (McLaren \& Michie, 1959; Barr, Jensh \& Brent, 1969; McKeown, Marshall \& Record, 1976) in other species so far examined. Likely factors accounting for such variation in the tenrec include variable numbers of fetuses associated with each arterial branch to the uterus, local variations in endometrium quality arising from the effects of previous pregnancies, and errors in fetal genotype. A high rate of resorption occurred in the early phase of implantation, suggesting that interchange through the placenta was insufficient as fetal demands increased with mass. In addition, the relative size of the placenta accounts for $41 \%$ of variation in fetal survival in the tenrec, with smaller mean placental size being associated with lower survival (Nicoll, 1985). The placenta can influence the quality and ratio of nutrients through its ability to synthesize amino acids, lipids and other compounds, including hormones which may influence maternal metabolism (Szabo \& Grimaldi, 1970; Burd et al., 1975; Jones, 1976). Whatever reasons are invoked, the observed variation in fetal weight of up to $273 \%$ is unusually high. For 2 other tenrec species, Echinops telfairi and S. setosus, there is slightly lower variation in neonate weights, and in the former at least, the smaller individuals die within the first week of birth (Gould \& Eisenberg, 1966; Godfrey \& Oliver, 1978). Differential fetal growth and survival may lead to selection of the most viable embryos. Selection acting on conceptuses is suggested by the spatial irregularity in resorption sites, the occurrence of runts, and the striking variation in fetal weight. This may be linked with the tenrecs' ability to be heterothermic, with periods of shallow torpor during pregnancy causing variation in gestation length at least in the tenrec (Nicoll, 1983), and perhaps also in two other species, E. telfairi and S. setosus (Eisenberg, 1975).

The litter size of tenrecs in the Seychelles is relatively large amongst mammals, ranging up to 13 
young (Nicoll, 1982), but is apparently lower than in Madagascar. Reliable comparative data (Kaudern, 1914; Rand, 1935; Bluntschli, 1938) give a range of 10-32 implantations with a median of 16 (mean \pm s.e.m. $17 \cdot 1 \pm 1 \cdot 9, n=12$ ) in Madagascar. This is significantly higher than the implantation rate in the Seychelles (range 3-18, median 11) (Mann-Whitney U test, 3.3, $P=$ $0 \cdot 0005$ ). In addition, up to 40 unimplanted blastocysts were counted in the reproductive tract of a Madagascar tenrec (Bluntschli, 1938), and litters of 19-32 foraging juveniles have been recorded (Kaudern, 1914; Bluntschli, 1938; Petter \& Petter-Rousseaux, 1963). MacArthur (1972) has suggested several reasons for populations on small islands having reduced reproductive rates. In addition, the Seychelles hot, humid rainforest environment results in smaller seasonal fluctuations in food supply (Nicoll, 1985) than those occurring in Madagascar. This is likely to provide less energetic scope for reproduction over carrying capacity of the environment. If this is an important factor determining litter size in the tenrec, litter size in Madagascar rainforest should be smaller than in drier woodland on the same island. The embryo counts of 8 females collected in Madagascar rainforests were $15 \cdot 1 \pm 2.5$ (s.e.m.) (Kaudern, 1914; Bluntschli, 1938). This sample included one count of 32 while the others numbered 10-16. Mean \pm s.e.m. number of embryos in drier regions of Madagascar was $19.5 \pm 1.8$ (range 18-25, $n=4$ ) (Rand, 1935), suggesting that litter size is smaller in rainforests.

We thank the Government of Seychelles for permission to carry out this research; Mr S. Savy and $\mathrm{Mr}$ L. Chong Seng for assistance in the field; M. F. Nicoll for assistance with histology; and Dr D. W. Thomas, Dr A. N. McWilliam, and Dr H. Q. P. Crick for useful discussion. This work was funded with a Leverhulme Overseas Studentship and an S.E.R.C. NATO Award to M.E.N., and grants from the Percy Sladen Memorial Fund and the Carnegie Trust for the Universities of Scotland to P.A.R.

\section{References}

Allen, P., Brambell, F.W.R. \& Mills, I.H. (1947) Studies on the sterility and prenatal mortality in wild rabbits. I. The reliability of estimates of prenatal mortality based on counts of corpora lutea, implantation sites and embryos. J. exp. Biol. 23, 312-331.

Barr, M., Jr, Jensh, R.P. \& Brent, R.L. (1969) Fetal weight and intra-uterine position in rats. Teratology 2, 241-246.

Bluntschli, H. (1938) Le dévéloppement primaire et l'implantation chez un centetine (Hemicentetes). C. $r$. Ass. Anat. 33, 39-46.

Bodemer, C.W. \& Warnick, S. (1961a) Polyovular follicles in the immature hamster ovary. I. Polyovular follicles in the normal intact animal. Fert. Steril. 12, $159-169$.

Bodemer, C.W. \& Warnick, S. (1961b) Polyovular follicles in the immature hamster ovary. II. The effects of gonadotrophic hormones in polyovular follicles. Fert. Steril. 12, 353-364.

Brambell, F.W.R. (1956) Ovarian changes. In Marshall's Physiology of Reproduction, 3rd edn, vol. 1, pt. 1, pp. 397-542. Ed. A. S. Parkes. Longmans Green, London.

Burd, L.I., Jones, M.D., Simmons, M.A., Makowski, E.L., Meschia, G. \& Battaglia, F.C. (1975) Placental production and foetal utilization of lactate and pyruvate. Nature, Lond. 254, 710-711.

Byskov, A.G-S. (1974) Does the rete ovarii act as a trigger for the onset of meiosis? Nature, Lond. 252, 396397.
Cohen, J.J. (1969) Is sexual reproduction wasteful? New Scientist 44, 282-285.

Collins, D.C. \& Kent, H.A. (1964) Polynuclear ova and polyovular follicles in the ovaries of young guinea pigs. Anat. Rec. 148, 115-119.

Dryden, G.L. (1969) Reproduction in Suncus murinus. J. Reprod. Fert., Suppl. 6, 377-396.

Dryden, G.L. \& Pucek, Z. (1976) Insectivores in reproduction studies, with emphasis on ovulation in American, Asian and European shrews. In The Laboratory Animal in the Study of Reproduction, pp. 39-50. Eds Th. Atikatzides, S. Erichsen \& A. Spiegel. Fischer Verlag, Stuttgart.

Eisenberg, J.F. (1975) Tenrecs and solenodons in captivity. Int. Zoo Yearb. 15, 6-12.

Eisenberg, J.F. \& Gould, E. (1970) The tenrecs: a study in mammalian behavior and evolution. Smithson. Contrib. Zool. 27, 1-127.

Godfrey, G.K. \& Oliver, W.L.R. (1978) The reproduction and development of the pygmy hedgehog tenrec Echinops telfairi. The Dodo 15, 38-51.

Gould, E. \& Eisenberg, J.F. (1966) Notes on the biology of the Tenrecidae. J. Mammal. 47, 660-686.

Harrison, R.J. (1962) The structure of the ovary. In The Ovary, Ist edn, vol. 1, pp. 143-187. Ed S. Zuckerman. Academic Press, New York.

Harrison, R.J. \& Weir, B.J. (1977) Structures of the mammalian ovary. In The Ovary, 2nd edn, vol. 1, pp. 113-217. Eds S. Zuckerman \& B. J. Weir. Academic Press, New York. 
Hartman, C.G. (1926) Polynuclear ova and polyovular follicles in the opossum and other mammals, with special reference to the problem of fecundity. Am.J. Anat. 37, 1-51.

Hartman, C.G. (1929) Some excessively large litters of eggs liberated in a single ovulation in mammals. $J$. Mammal. 10, 197-202.

Hesselton, W.T. (1967) Two further incidents of polyovulation in white-tailed deer in New York. J. Mammal. 48, 321 .

Hesselton, W.T., Tanck, J.E. \& Rice, D.T. (1964) An unusual pregnancy in a white-tailed deer in New York. J. Mammal. 45, 151.

Hill, J.P. (1910) The early development of the marsupial, with special reference to the native cat (Dasyurus viverrinus). $Q$. Jl microsc. Sci. 56, 1-134.

Jones, C.T. (1976) Fetal metabolism and fetal growth. $J$. Reprod. Fert. 47, 189-201.

Kaudern, W. (1914) Einige Beobachtungen über die Zeit der Fortpflanzung der madagassischen Säugetiere. Arkiv, für Zoologie 9, 1-22.

Kent, H.A. (1959) Reduction of polyovular follicles and polynuclear ova by oestradiol monobenzoate. Anat. Rec. 134, 455-462.

Kent, H.A. (1960) Polyovular follicles and multinucleate ova in the ovaries of young mice. Anat. Rec. 137, 521524.

Kent, H.A. (1962) Polyovular follicles and polynuclear ova in the ovaries of young hamsters. Anat. Rec. 143, 345-349.

Kent, H.A. \& Mandel, J.A. (1968) Correlation of ovarian abnormalities in young golden hamsters with blood estrogen content. Anat. Rec. 161, 53-56.

Landau, R. (1938) Der ovariale und tubale Abschnitt des Genitaltraktus beim nicht-graviden und beim früh graviden Hemicentetes - Weibchen. Biomorphosis 1, 228-264.

Leach, B.J. \& Conaway, C.H. (1963) Origin and fate of polyovular follicles in the striped skunk. J. Mammal. 44, 67-74.

McArthur, R.H. (1972) Geographical Ecology: Patterns in the Distribution of Species. Harper \& Row, New York.

Mckeown, T., Marshall, T. \& Record, R.G. (1976) Influences on fetal growth. J. Reprod. Fert. 47, 167181.

McLaren, A. \& Michie, D. (1959) The spacing of implantations in the mouse uterus. Mem. Soc. Endocr. 6, 65-75.
Nicoll, M.E. (1982) Reproductive ecology of Tenrec ecaudatus (Insectivora: Tenrecidae) in the Seychelles. Ph.D. thesis, University of Aberdeen.

Nicoll, M.E. (1983) Mechanisms and consequences of large litter production in Tenrec ecaudatus (Insectivora: Tenrecidae). Annls Mus. r. Afr. cent. Sér. 4 to Zool. 237, 219-226.

Nicoll, M.E. (1985) Responses to Seychelles tropical forest seasons by a litter-foraging mammalian insectivore, Tenrec ecaudatus, native to Madagascar. $J$. Anim. Ecol. 54, 71-88.

Parkes, A.S. (1931) The reproductive processes of certain mammals. II. The size of the Graafian follicle at ovulation. Proc. R. Soc. B 109, 185-196.

Pearson, O.P. (1944) Reproduction in the shrew (Blarina brevicauda Say.). Am. J. Anat. 75, 39-93.

Petter, J.J. \& Petter-Rousseaux, A. (1963) Notes biologiques sur les Centetinae. Terre et Vie 17, 66-80.

Price, M. (1953) The reproductive cycle of the water shrew Neomys fodiens bicolor Shaw. Proc. zool. Soc. Lond. 123, 599-621.

Racey, P.A. \& Nicoll, M.E. (1984) Mammals of the Seychelles. In Biogeography and Ecology of the Seychelles Islands, pp. 607-626. Ed. D. Stoddart. W. Junk, The Hague.

Rand, A.L. (1935) On the habits of some Madagascar mammals. J. Mammal. 16, 89-104.

Shehata, R. (1974) Polyovular Graafian follicles in a newborn kitten with a study of polyovuly in the cat. Acta anat. 89, 21-30.

Strauss, F. (1938) Die Befruchtung und der Vorgang der Ovulation bei Ericulus aus der Familie der Centetiden. Biomorphosis 1, 281-312.

Strauss, F. (1939) Die Bildung der Corpus luteum bei Centetiden. Biomorphosis 1, 489-544.

Szabo, A.J. \& Grimaldi, R.D. (1970) The metabolism of the placenta. Adv. Met. Disord. 4, 185-228.

Tripp, H.R.H. (1971) Reproduction in elephant shrews (Macroscelididae) with special reference to ovulation. J. Reprod. Fert. 26, 149-159.

Weir, B.J. (1971a) The reproductive organs of the plains viscacha, Lagostomus maximus. J. Reprod. Fert. 25, 365-373.

Weir, B.J. (1971b) The reproductive physiology of the plains viscacha, Lagostomus maximus. J. Reprod. Fert. 25, 355-363.

Received 17 June 1984 